J. Perinat. Med. 4 (1976) 255

\section{A descriptive method for automatically analysing uterine forces during labor}

\author{
F. Donati, F. Ferraris, L. Gagliardi, S. Rustichelli
}

Gruppo Automatica e Informatica, Istituto Elettrotecnico Nazionale Galileo Ferraris

Centro Elaborazione Numerale dei Segnali, Torino

Istituto di Patologia Ostetrica e Ginecologica dell'Università, Tọrịno

Istituto di Prima Clinica Ostetrica e Ginecologica dell'Università, Torino
The importance of variations in intrauterine pressure for uterine contraction has been known since the last century $[35,36]$. Only more recently has research in this field received an important improvement, $[2,3,5,6,20,21,22,23]$. The reason for this can be found in the introduction into obstetrical management of recording of amniotic fluid pressure variations $[1,14,15,24,30,39]$.

At present, one of the main results was the definition of units of uterine activity. The "Montevideo" and "Alexandria" units proposed respectively by CAldey Ro-BARCiA [3,4] and El-SAKwi [11] can be mentioned as examples of single indices, which point out the more evident pathological aspects connected with labor.

These very simple indices can help physicians to get a rough evaluation of labor behaviour. They are limited by their own simplicity. It is very difficult, even impossible, to summarize labor evaluation with only one index. Many parameters which characterize the shape, frequency and tones of contraction patterns, may be themselves important and could indicate the presence of pathological factors.

At present it is not well known which parameters indicate the presence of pathological factors, even though some qualitative indications have been mentioned $[8,10,17,18,19,25,27,28,29$, $37,38]$.

\section{Curriculum vitae}

FRANCESCODONATIwas born in Arezzo (Italy) on December 16, 1936. He received the Doctor degree in electrotechnicalengineering from the Politecnico of Torino (Italy) in 1960, the "Libera Docenza" degree in electrotechnical science in 1967.

In 1961 he joined the "Istituto Elettrotecnico Nazionale G. Ferraris" of Torino as a researcher in the Electric Power Department; in 1971 he became chief of the Automatic Control Division.

Since 1973 he has the chair of Applicazioni Elettromeccaniche" at the Politecnico of Torino and since 1974 he is Director of the Electric Machines Institute of the same Politecnico.

His principal research area is the system theory, particularly the fuzzy system. modelling, identification and control.

Given an intrauterine pressure oscillogram, quantitative evaluations of many parameters which could indicate pathological changes are almost impossible, if only simple manual facilities, as, for example, the "planimeter" are used $[9,16,31-34]$. In any case such a manual evaluation requires too much time in order to carry out statistical studies on a large number of cases. At the same time a 
simple intrauterine pressure oscillogram does not seem suitable for monitoring purposes. The manual computation of indices, even if they are as simple as the Montevideo and Alexandria units, is not very rewarding.

The aim of this paper is to study a procedure of intrauterine pressure signal analysis, which allows the description of uterine contraction, by a set of parameters that are both interesting for research purposes in labor and suitable for continuous monitoring. The set of parameters was chosen in order to repeat quantitatively the qualitative analysis which a physician can make by a simple inspection of the pressure signal oscillogram.

Altogether each uterine contraction has been described by a set of twenty-five parameters (see Tables I, II, V) which summarize all the interesting aspects of waveform contraction for research and monitoring purposes.

The main difficulty was the recognition of contraction. A contraction can have many different aspects, both in behaviour and in amplitude. Moreover an effective contraction can be distinguished from other pressure improvements produced by coughing or similar causes, making use of different considerations which are usually more qualitative than quantitative. The difficulties have been overcome by using a pattern recognition algorithm based on a structural representation of the contraction $[12,13,16,26]$.

The analytical method is described in Sect. II. In Sect. III the first results obtained with the computer procedure are presented. In Sect. IV the actual hardware configuration and the future monitoring system are described.

\section{Analysis procedure}

Some waveforms of the intrauterine pressure signal are reproduced in Fig. 1. Cases a), b), c), d), are related to normal contractions. Even if they may appear similar, they differ among themselves, mainly in amplitude, duration and smoothness. Case e) differs largely from all the others, even if this contraction belongs to the same labour period as case a). It represents two typical paired contractions.

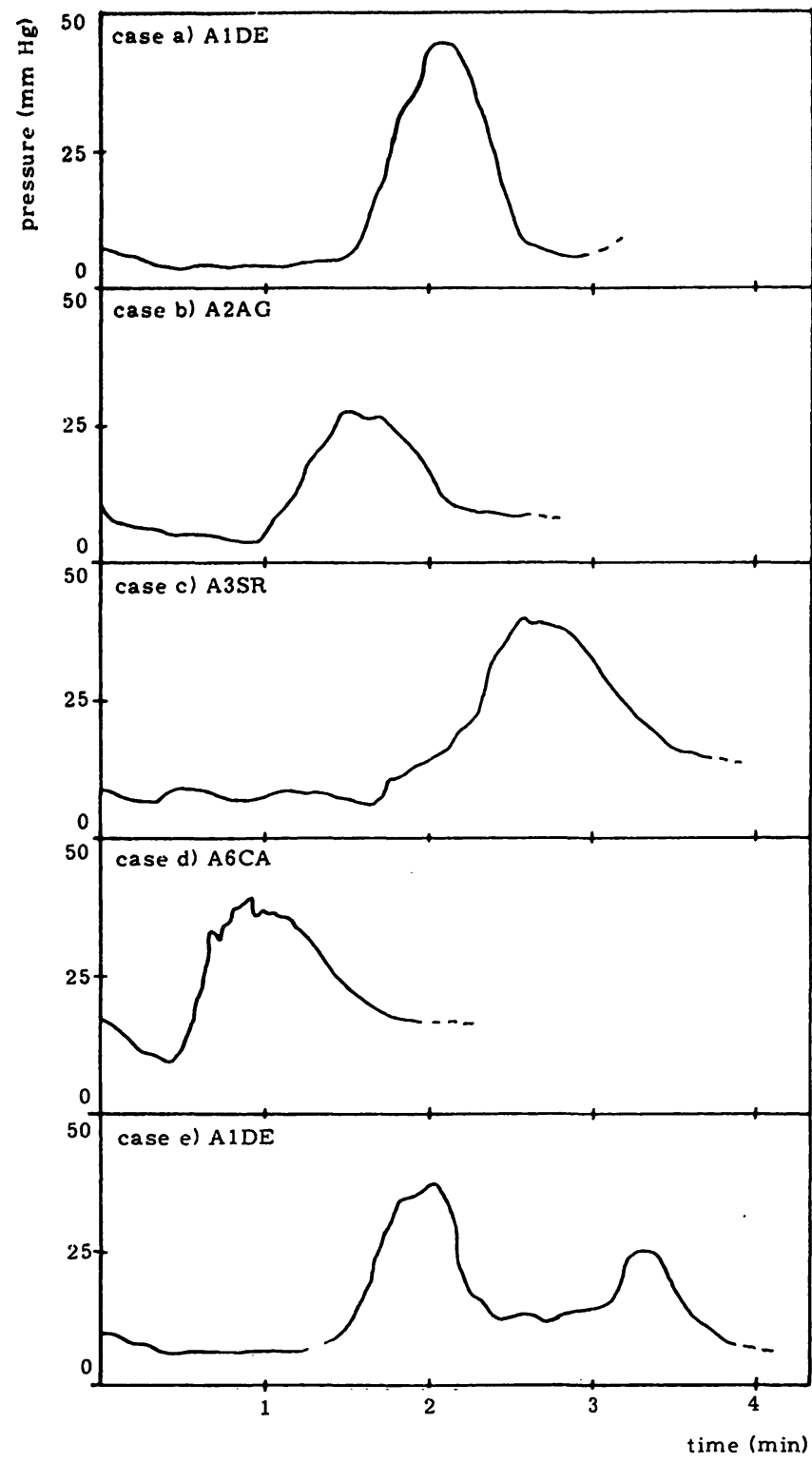

Fig. 1. Intrauterine pressure signal. Some contraction waveforms - Note that the waveforms have been smoothed in order to give a clearer picture.

In spite of the variability in the contraction waveform it is not difficult to recognize some standard characteristics. Following an interval along which it maintains an almost constant low value (basal tone), the intrauterine pressure rises, reaches and maintains high values (contraction); the pressure behaviour in this last interval can be more or less smooth. Then the pressure falls and reaches a new low value (basal tone) which is almost constant for a long period, until a new contraction begins.

The scheme of a typical pressure wave is pictured in Fig. 2, where the basal tone time interval is 


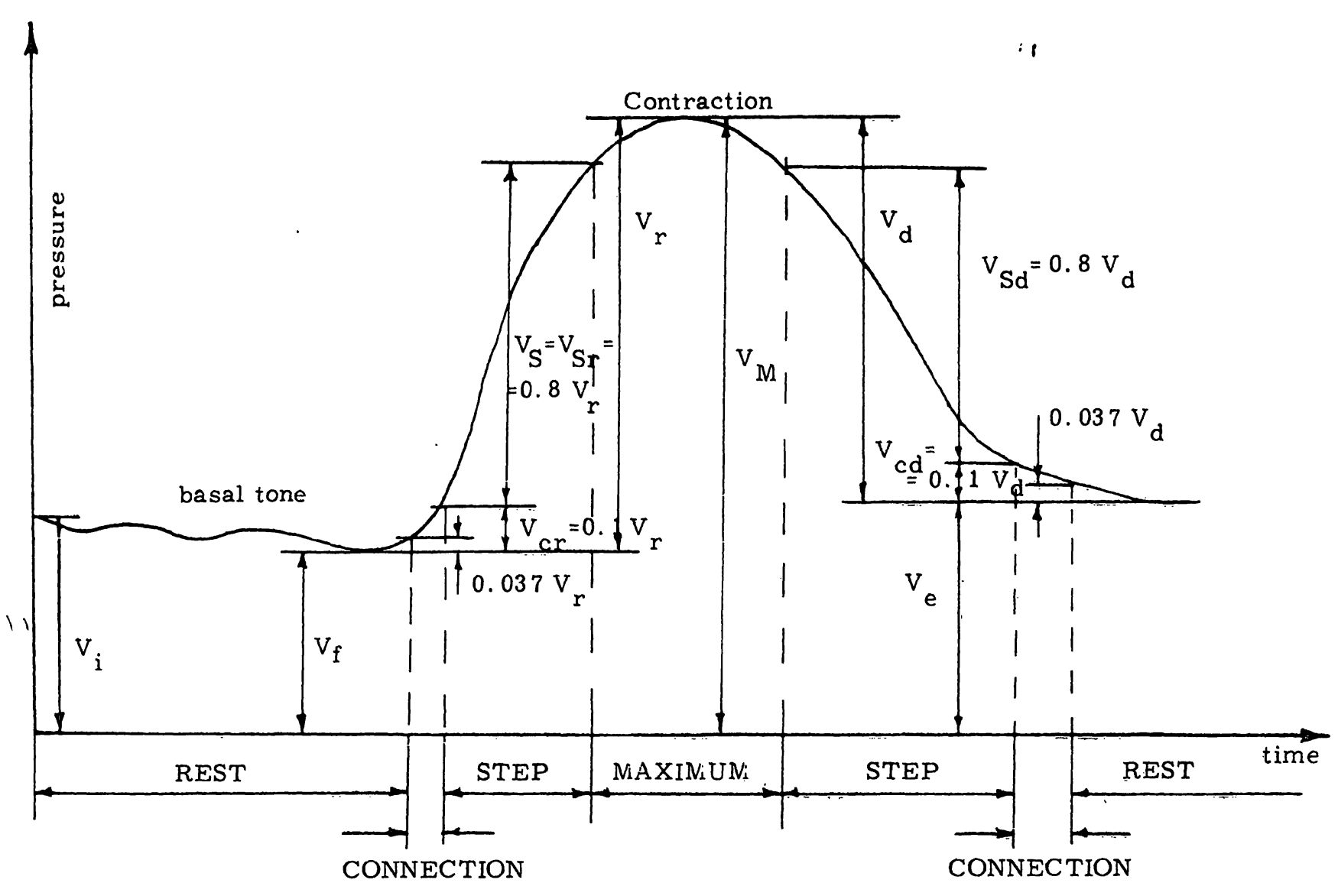

Fig. 2. Typical waveform in contraction.

associated with the following contraction. On the basis of this standard behaviour pattern the contraction has been divided into six zones, namely: REST, RISE-CONNECTION, RISE-STEP, MAXIMUM, SLOPE-STEP,SLOPE-CONNECTION.

In the REST zone the amniotic fluid pressure is characterized by a low value which is normally constant, but can sometime present a "drift" or irregular behaviour.

In the RISE-CONNECTION zone, the pressure begins to increase. The zone is characterized by the "speed" of the pressure rise.

In the RISE-STEP zone the pressure moves upwards. The pressure rise-time is defined. The behaviour of the wave can be smooth or irregular.

In the MAXIMUM zone, the pressure reaches its maximum value; the pressure signal may have one or more maxima and its behaviour may be smooth or irregular.
In the SLOPESTEP zone the pressure moves downwards. This zone has the same characteristics as the RISE-STEP zone.

At last in the SLOPE-CONNECTION zone, the pressure stops decreasing.

In order to define the initialf and final point of each zone the intrauterine pressure signal is smoothed by a filter, which, without introducing phase distortion, presents a cut off frequency of $0.1 \mathrm{~Hz}$. Each zone is also shown in Fig. 2.

In terms of a pattern recognition procedure, the structural representation of a contraction has a fixed "surface structure" [7] corresponding to' the following "phrase":

\section{REST, CONNECTION, STEP, MAXIMUM.}

Each element of the phrase consists of a primitive feature followed by several attributes, which describe the particularities of each zone of the considered uterine contraction. The choice of 
these attributes is an important step, since they represent the parameters for the characteristics of uterine contraction which are proposed for the study of uterine pressure waveforms. The attributes, are listed in Tab. I.

Tab. I. The different elements of the "phrase".

\begin{tabular}{|c|c|c|c|}
\hline \multirow{2}{*}{$\begin{array}{l}\text { Primitive } \\
\text { Element }\end{array}$} & \multicolumn{2}{|c|}{ Attributes } & \multirow[b]{2}{*}{ Unit } \\
\hline & Symbol & Notation & \\
\hline REST & $\begin{array}{l}L \\
V_{m} \\
V_{i} \\
V_{f} \\
V_{s}\end{array}$ & $\begin{array}{l}\text { Duration } \\
\text { Pressure mean value } \\
\text { Pressure initial value } \\
\text { Pressure final value } \\
\text { Pressure standard } \\
\text { deviation (1) }\end{array}$ & $\begin{array}{l}\mathrm{sec} \\
\mathrm{mm} \mathrm{Hg} \\
\mathrm{mm} \mathrm{Hg} \\
\mathrm{mm} \mathrm{Hg} \\
\mathrm{mm} \mathrm{Hg}\end{array}$ \\
\hline $\begin{array}{l}\text { CONNEC- } \\
\text { TION }\end{array}$ & L & Duration & sec \\
\hline STEP & $\begin{array}{l}\mathrm{L} \\
\mathrm{V}_{\mathrm{S}} \\
\mathrm{V}_{\mathrm{c}} \\
\mathrm{V}_{\mathrm{sH}}\end{array}$ & $\begin{array}{l}\text { Duration } \\
\text { Pressure step value } \\
\text { Concavity index (3) } \\
\text { High frequency pres- } \\
\text { sure standard deviation } \\
\text { (2) }\end{array}$ & $\begin{array}{l}\mathrm{sec} \\
\mathrm{mm} \mathrm{Hg} \\
\% \\
\mathrm{~mm} \mathrm{Hg}\end{array}$ \\
\hline MAXIMUM & $\begin{array}{l}\mathrm{L} \\
\mathrm{V}_{\mathrm{m}} \\
\mathrm{N} \\
\mathrm{V}_{\mathrm{M}}(\mathrm{I}) \\
\mathrm{V}_{\mathrm{S}} \\
\mathrm{V}_{\mathrm{sH}}\end{array}$ & $\begin{array}{l}\text { Duration } \\
\text { Pressure mean value } \\
\text { Number of peaks } \\
\text { Value of peak I } \\
\text { Pressure standard } \\
\text { deviation (1) } \\
\text { High frequency pres- } \\
\text { sure standard deviation } \\
\text { (2) }\end{array}$ & $\begin{array}{l}\mathrm{sec} \\
\mathrm{mm} \mathrm{Hg} \\
\mathrm{mm} \mathrm{Hg} \\
\mathrm{mm} \mathrm{Hg} \\
\mathrm{mm} \mathrm{Hg}\end{array}$ \\
\hline $\begin{array}{rl}(1)-V_{s} & i \\
(2)-V_{s H} & i \\
(3)-V c i & i \\
& i \\
s\end{array}$ & \multicolumn{3}{|c|}{$\begin{array}{l}\text { is the mean square value of the pressure differ- } \\
\text { ence from its mean value. } \\
\text { is the mean square value of the signal compo- } \\
\text { nents at frequencies greater than } 0.1 \mathrm{~Hz} \text {. } \\
\text { is an index of concavity of the pressure signal } \\
\text { waveform in the STEP zone referring to an } \\
\text { ideal behaviour pattern represented by a } \\
\text { straight line. If } \mathrm{V}_{c} \text { is greater than zero the } \\
\text { concavity turns up. }\end{array}$} \\
\hline
\end{tabular}

Note that these attributes are not proposed in order to directly indicate the presence of pathological foetons, but rather to summarize all the interesting clinical aspects of the contraction waveform.

In order to give a complete description of the contraction wave, a further element of "terminal vocabulary" is needed, namely "CONTRACTION", which is a primitive term whose attributes characterize the behaviour of the entire contraction wave. These attributes are listed in Tab. II.

Tab. II. Attributes of the contraction wave.

\section{CONTRACTION Attributes}

\begin{tabular}{lll} 
Symbol & Notation & Unit \\
\hline$L$ & Duration & $\mathrm{sec}$ \\
$\mathrm{V}_{\mathrm{m}}$ & Pressure mean value & $\mathrm{mm} \mathrm{Hg}$ \\
$\mathrm{V}_{\mathrm{s}}$ & Pressure standard deviation & $\mathrm{mm} \mathrm{Hg}$ \\
$\mathrm{V}_{\mathrm{sH}}$ & $\begin{array}{l}\text { High frequency pressure standard } \\
\text { deviation }\end{array}$ & $\mathrm{mm} \mathrm{Hg}$ \\
\hline
\end{tabular}

The followingnon terminal elements are introduced: UNIT, PMAX, BEGINNING, WAVE, END, RISE, SLOPE. Each element has a set of attributes, which is listed in Tab. III.

A "start element", LABOR, is also defined. The generative model for the contraction is a tree shown in Fig. 3.

The variety of possible realizations is obtained by appointing different values to the attributes of the terminal elements. The tree in Fig. 3 is represented more adequately by the set of rules reported in Tab. III. These rules are very simple but are true only if some conditions of the attributes are satisfied. These conditions are reported in the last column in Tab. III. The algorithm for recognizing a contraction is a TOP-DOWN procedure following five steps.

I) At the beginning of labor analysis UNIT is generated by LABOR; then it is generated by the END of the previous analysis of uterine contraction. The values of UNIT attributes $\left(V_{h}, V_{l}\right)$ result from previous computations performed by LABOR or END. In both cases they represent the minimum and maximum value within which the pressure presumably will range during the contraction period.

II) Then a maximum of intrauterine pressure is found, whose value $V_{M}$ must satisfy the inequality:

$$
V_{M}>f_{1}\left(V_{h}, V_{1}\right)
$$

in terms of the pattern recognition technique it results:

UNIT $\rightarrow$ PMAX. 


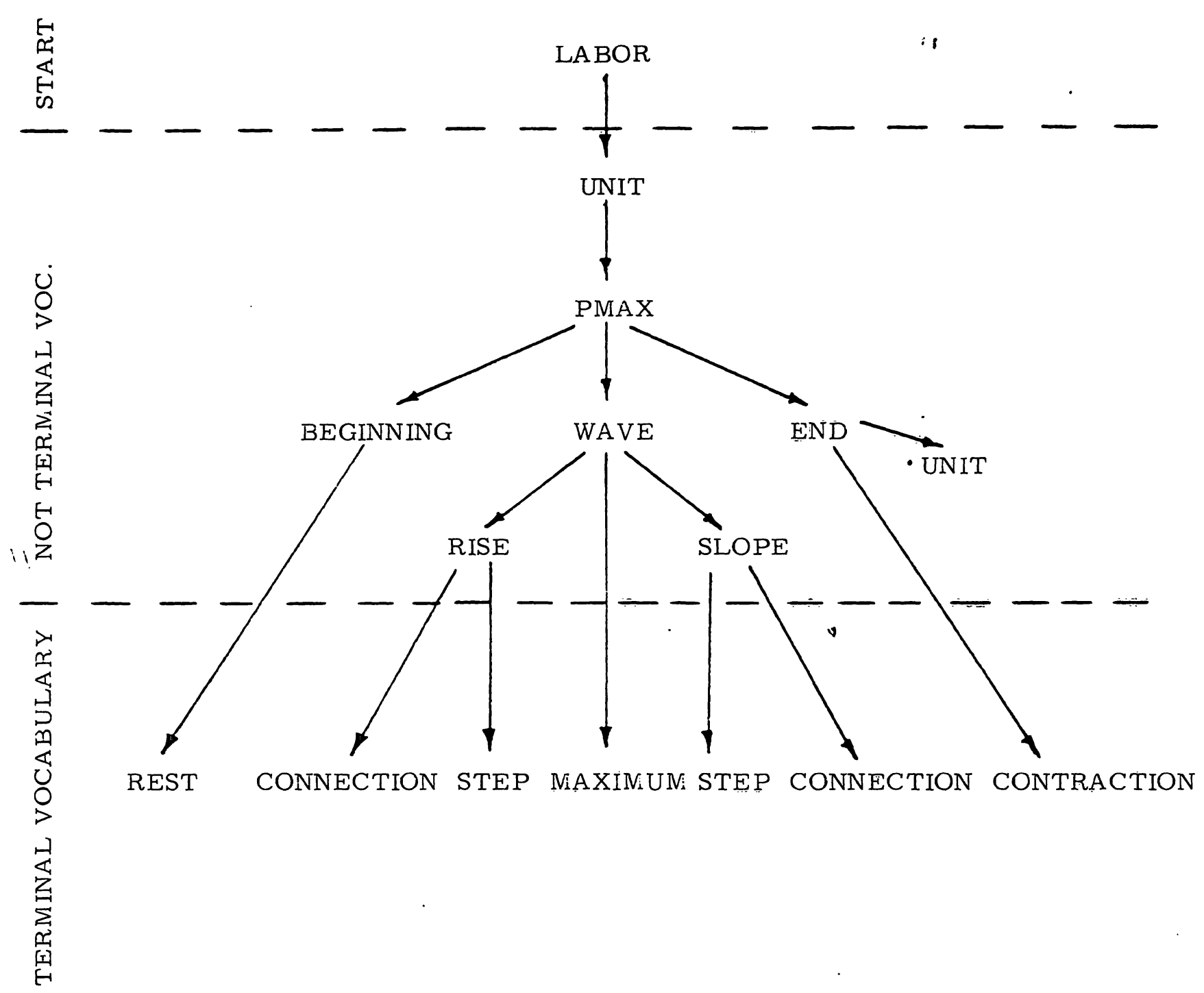

Fig. 3. Tree of recognition procedure.

The function $f_{1}\left(V_{h}, V_{1}\right)$ gives a suitable value less than $V_{h}$ and greater than $V_{l}$. The choice of this function is important in order to distinguish the contractions from the other irregularities of the pressure signal by means of their peak value.

III) The following step, i.e.

\section{PMAX $\rightarrow$ BEGINNING WAVE END}

is achieved, when the initial and final point of the contraction have been identified. According to the rules listed in Tab. III, the following particular tests are carried out:

a) the pressure signal must be rather constant after the final point of contraction $\mathrm{V}_{\mathrm{e}}$ and before starting point $V_{\mathrm{f}}$. This condition requires the signal to be constant with a short drift of about fifteen seconds. b) $V_{e}<f_{2}\left(V_{M}, V_{i}\right)$. This test requires the pressure value to be at the identified final point of the contraction $V_{e}$ to be lower than a threshold $f_{2}\left(V_{M}, V_{i}\right)$ calculated as a function of the maximum peak value $V_{m}$ and the starting value $V_{i}$ of the contraction; this threshold has been computed in order to avoid a false end point.

c) $\tau>20$ seconds. This further test requires a contraction duration (computed as the interval time between the $V_{f}$ and $V_{e}$ pressure signal point; also see Fig. 2) not shorter than twenty seconds. The aim of this test is to separate the contractions from the other pressure improvements produced by coughing or similar caúses. When this step in analysis is achieved, the contraction and the previous REST interval time are completely identified and the samples of the signal are memorized in the memory of the computer.

IV) The memorized data are, now, processed in. order to identify the zones into which the contraction time interval must be subdivided and to 
Tab. III. Attributes of each element.

\section{Generation rules}

This element

generates these elements

(the attributes are in brackets)

with the bonds

LABOR
$\operatorname{UNIT}\left(V_{h}, V_{l}\right)$
$\operatorname{PMAX}\left(V_{h}, V_{i}, V_{M}\right)$

$\operatorname{BEGINNING}\left(\mathrm{V}_{\mathrm{i}}, \mathrm{V}_{\mathrm{f}}\right)$

WAVE $\left(\mathrm{V}_{\mathrm{M}}, \mathrm{V}_{\mathrm{f}}, \mathrm{V}_{\mathrm{e}}, \tau\right)$

$\operatorname{RISE}\left(\mathrm{V}_{\mathrm{f}}, \mathrm{V}_{\mathrm{r}}, \mathrm{V}_{\mathrm{cr}}, \mathrm{V}_{\mathrm{Sr}}\right)$

$\operatorname{SLOPE}\left(\mathrm{V}_{\mathrm{e}}, \mathrm{V}_{\mathrm{d}}, \mathrm{V}_{\mathrm{cd}}, \mathrm{V}_{\mathrm{Sd}}\right)$

$\operatorname{END}\left(\mathrm{V}_{\mathrm{i}}, \mathrm{V}_{\mathrm{M}}, \mathrm{V}_{\mathrm{e}}\right)$
UNIT $\left(V_{h}, V_{1}\right)(1)$
$\operatorname{PMAC}\left(V_{h}, V_{i}, V_{M}\right)$

BEGINNING $\left(V_{i}, V_{f}\right)$ WAVE $\left(V_{M}\right.$, $\left.V_{f}, V_{e}, \tau\right)$ END $\left(V_{i}, V_{M}, V_{e}\right)(1)$

$$
\begin{aligned}
& \operatorname{REST}\left(\mathrm{L}, \mathrm{V}_{\mathrm{m}}, \mathrm{V}_{\mathrm{i}}, \mathrm{V}_{\mathrm{f}}, \mathrm{V}_{\mathrm{s}}\right) \\
& \operatorname{RISE}\left(\mathrm{V}_{\mathrm{f}}, \mathrm{V}_{\mathrm{r}}, \mathrm{V}_{\mathrm{cr}}, \mathrm{V}_{\mathrm{Sr}}\right) \text { MAXIMUM } \\
& \left(\mathrm{L}, \mathrm{V}_{\mathrm{m}}, \mathrm{N}, \mathrm{V}_{\mathrm{M}}(\mathbf{I}), \mathrm{V}_{\mathrm{s}}, \mathrm{V}_{\mathrm{sH}}\right) \text { SLOPE } \\
& \left(\mathrm{V}_{\mathrm{e}}, \mathrm{V}_{\mathrm{d}}, \mathrm{V}_{\mathrm{cd}}, \mathrm{V}_{\mathrm{Sd}}\right)
\end{aligned}
$$$$
\text { RISE }\left(V_{f}, V_{r}, V_{c r}, V_{S r}\right) \text { MAXIMUM RISE before MAXIMUM }
$$

CONNECTION (L) STEP (L, $\mathrm{V}_{\mathrm{S}}$, $\left.\mathrm{V}_{\mathrm{c}}, \mathrm{V}_{\mathrm{sH}}\right)$ $\operatorname{STEP}\left(\mathrm{L}, \mathrm{v}_{\mathrm{S}}, \mathrm{v}_{\mathrm{c}}, \mathrm{v}_{\mathrm{sH}}\right)$ CONNECTION

(L) CONTRACTION $\left(\mathrm{L}, \mathrm{v}_{\mathrm{m}}, \mathrm{v}_{\mathrm{s}}, \mathrm{v}_{\mathrm{sH}}\right)$ $\operatorname{UNIT}\left(\mathbf{V}_{\mathbf{h}}, \mathrm{V}_{\mathbf{l}}\right)$

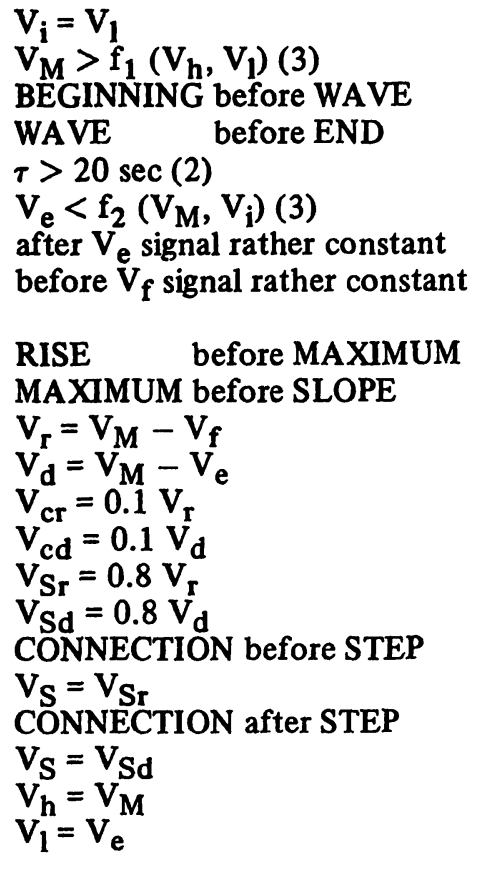

(1) $V_{h}, V_{l}$ are values of the preceding contraction, while $V_{M}, V_{e}$ are values of this contraction; $V_{h}$ and $V_{M}$ are the maximum peak values; $V_{1}$ and $V_{e}$ are the last value of the contraction (also see fig. 2).

(2) $\tau$ is the contraction interval time (when the REST zone is excepted) which must be greater than twenty seconds.

(3) $f_{1}(A, B)$ and $f_{2}(A, B)$ are assigned functions of the $A, B$ values.

The further attributes are defined in Table $I$ or in fig. 2.

compute the parameters which characterize each zone.

The analysis is carried out following these steps:

\section{WAVE $\rightarrow$ RISE MAXIMUM SLOPE \\ RISE $\rightarrow$ CONNECTION STEP \\ SLOPE $\rightarrow$ STEP CONNECTION BEGINNING $\rightarrow$ REST}

To identify each zone, the bonds listed in Tab. III must be satisfied.

V) Now a complete description of each zone of the processed contraction has been accomplished; the analysis also computes the parameters which characterize the entire wave and the $V_{h}, V_{1}$ values which are needed for the identification of the next contraction, by the following step:

\section{END $\rightarrow$ CONTRACTION UNIT}

Then starting from UNIT the analysis of the following uterine contraction begins.

\section{Observed cases and results}

In order to verify the significance of the parameters defined in section two, spontaneous labors (neither induced nor maintained by drugs) were selected.

The obstetric case history and clinical situation of five cases are described in Tab.IV. Some contraction waves of these labors are also pictured in Fig. 1. In Tab. $\mathrm{V}$ the twenty-five parameters obtained from the contractions shownin Fig. 1 are presented as examples.

The first result obtained indicates that the proposed procedure is suitable, both when the contractions give pressure signals like the smoothed model wave 
Tab. IV. Case history and clinical situation

$: 1$

\begin{tabular}{|c|c|c|c|c|}
\hline N. & $\begin{array}{l}\text { Parity (1) } \\
\text { age (years) }\end{array}$ & $\begin{array}{l}\text { Gestational } \\
\text { age (weeks) }\end{array}$ & $\begin{array}{l}\text { Clinical condition: } \\
\text { the arialysis begins }\end{array}$ & $\begin{array}{l}\text { Clinical condition } \\
\text { at the end of analysis }\end{array}$ \\
\hline A1 DE & $\begin{array}{l}0000 \\
17\end{array}$ & 40 th & $\begin{array}{l}\text { Initial labor } \\
\text { Artificial amniorexis } \\
\text { Cervix 4-5 cm dilated } \\
\text { Cephalic presentation }\end{array}$ & Fully dilated cervix \\
\hline A2 AG & $\begin{array}{l}2031 \\
31\end{array}$ & 40 th & $\begin{array}{l}\text { Initial labor } \\
\text { Artificial amniorexis } \\
\text { Cervix } 4-5 \mathrm{~cm} \text { dilated } \\
\text { Cephalic presentation }\end{array}$ & Fully dilated cervix \\
\hline A3 SR & $\begin{array}{l}0000 \\
23\end{array}$ & 41 th & $\begin{array}{l}\text { Initial labor } \\
\text { Artificial amniorexis } \\
\text { Cervix } 5 \mathrm{~cm} \text { dilated } \\
\text { Cephalic presentation }\end{array}$ & Cervix $6 \mathrm{~cm}$ dilated \\
\hline '́ $44 \mathrm{AL}$ & $\begin{array}{l}0010 \\
24\end{array}$ & 40 th & $\begin{array}{l}\text { From } 7 \text { hours in labor } \\
\text { Spontaneous amniorexis } \\
\text { Cervix } 3-4 \mathrm{~cm} \text { dilated } \\
\text { Cephalic presentation }\end{array}$ & Fully dilated cervix \\
\hline A6 CA & $\begin{array}{l}0000 \\
28\end{array}$ & 40 th & $\begin{array}{l}\text { Initial labor } \\
\text { Artificial amniorexis } \\
\text { Cervix } 5 \mathrm{~cm} \text { dilated } \\
\text { Cephalic presentation }\end{array}$ & Fully dilated cervix \\
\hline
\end{tabular}

(1) The parity is a description of the obstetric conditions of the patient:

a) the first digit is the number of pregnancies with a delivery at term;

b) the second digit is the number of premature deliveries;

c) the third digit is the number of abortions;

d) the last digit is the number of living children.

pictured in Fig. 2, (because the extracted parameters are included in the normal rate), and also when the contractions have a more irregular behaviour, where some parameters reach abnormal values.

The Montevideo and Alexandria units of each recorded labour were also considered: The values compared with those calculated by the usual technique were the same.

This proposed computer procedure was designed to analyse contractions during the dilatation phase of labor: Hence it should be unable to process waves of the expulsive labor phase. However the procedure identifies exactly the beginning of this phase because some parameters reach characteristic values: For example the high frequency pressure standard deviation $\left(\mathrm{V}_{\mathrm{sH}}\right)$ and the number and the value of peaks $\left(\mathrm{N}_{\mathrm{b}}, \mathrm{V}_{\mathrm{M}}(\mathrm{I})\right)$ strongly and quickly increase.

\section{Instrumentation}

The instrumentation block scheme is represented in Fig. 4: The signal was borne by a probe according to the intra-amniotic uterine technique. It was recorded by an analogue magnetic four channel FM tape recorder (the speed was $15 / 16 \mathrm{ips}$ ). The recorded signal was filtered by a low pass BUTTERWORTH four pole filter, sampled and processed by a general purpose computer; the A/D conversion rate was $10 \mathrm{~Hz}$, the amplitude scale precision was nine bits plus sign; the parameters are computed and the results listed by a line-printer.

The analysis procedure is planned as a background for continuous monitoring during labor. This background will be employed for the definition and computation' of new indices, functions of the proposed parameters.

The hardware configuration for monitoring will be settled by a process computer connected on-line to controlled labour as is indicated in Fig. 5. Many cases of labors can be monitored at the same time. A display will show the indices for each labor period and their normal range. The parameters of each contraction will be recorded by a digital magnetic tape for successive statistical analysis, which will be performed off-line üsing a general purpose 
Tab. V

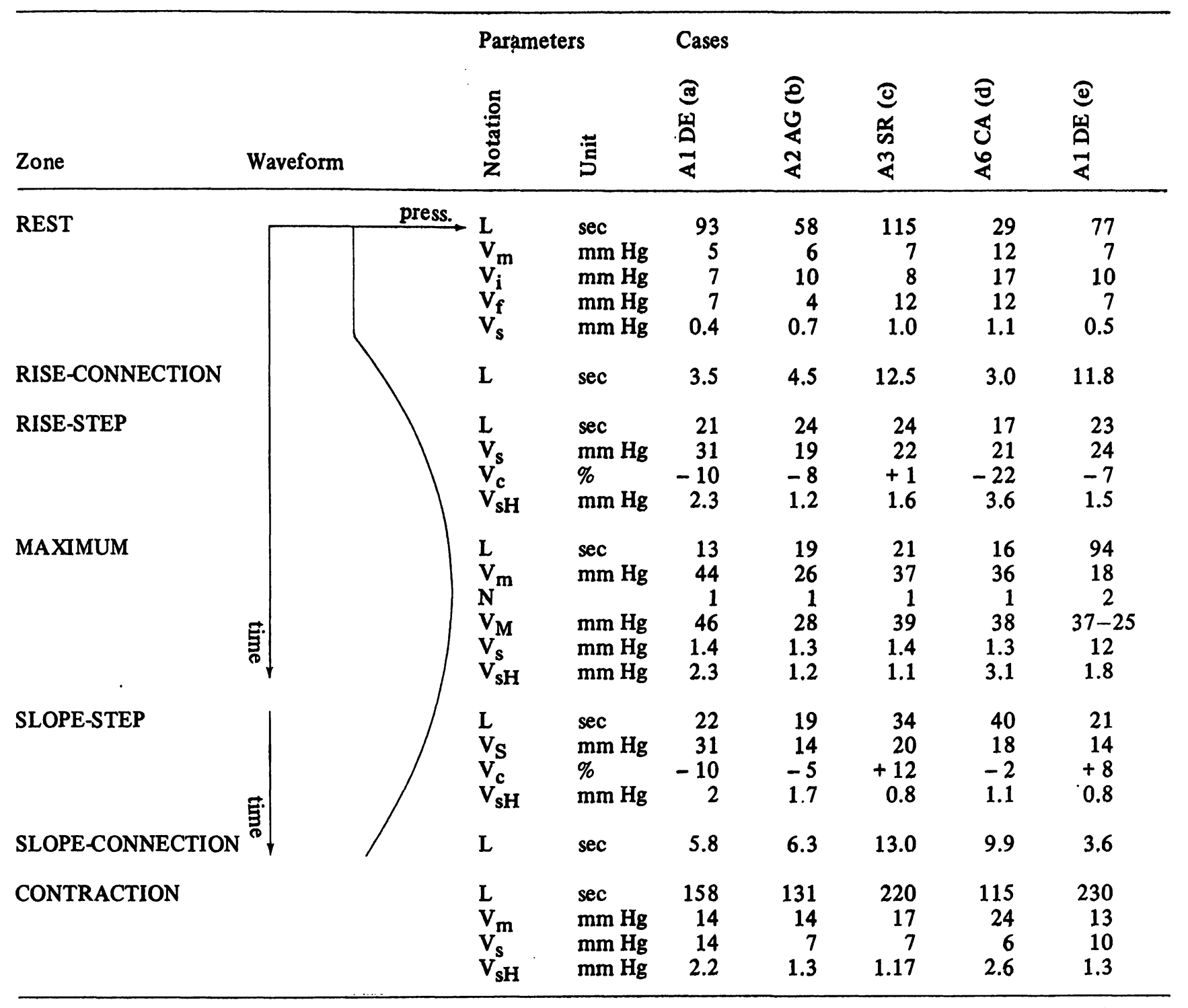

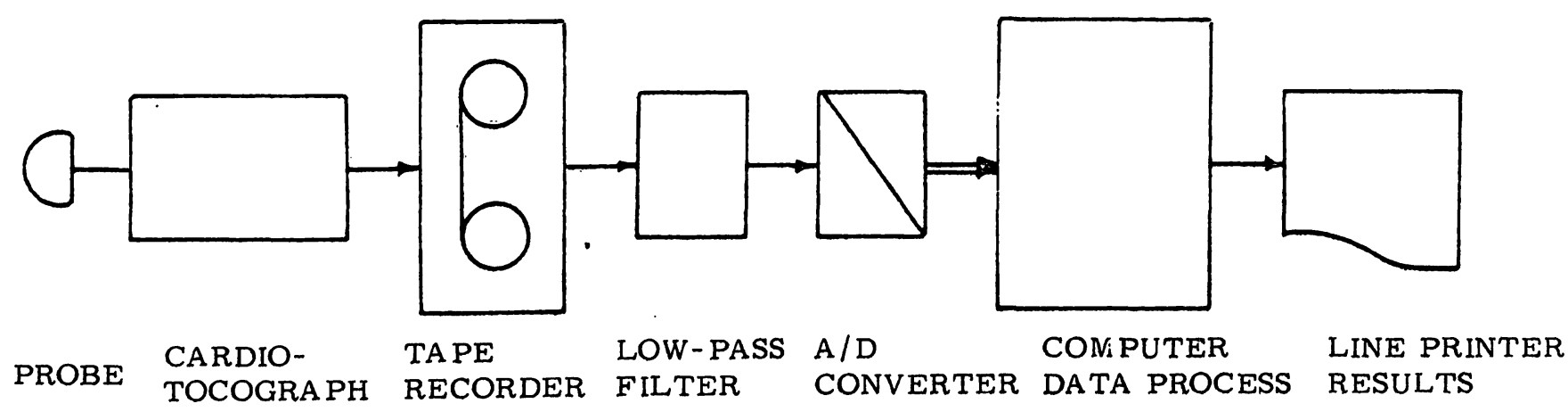

Fig. 4. Off-line analysis procedure.

J. Perinat. Med. 4 (1976) 


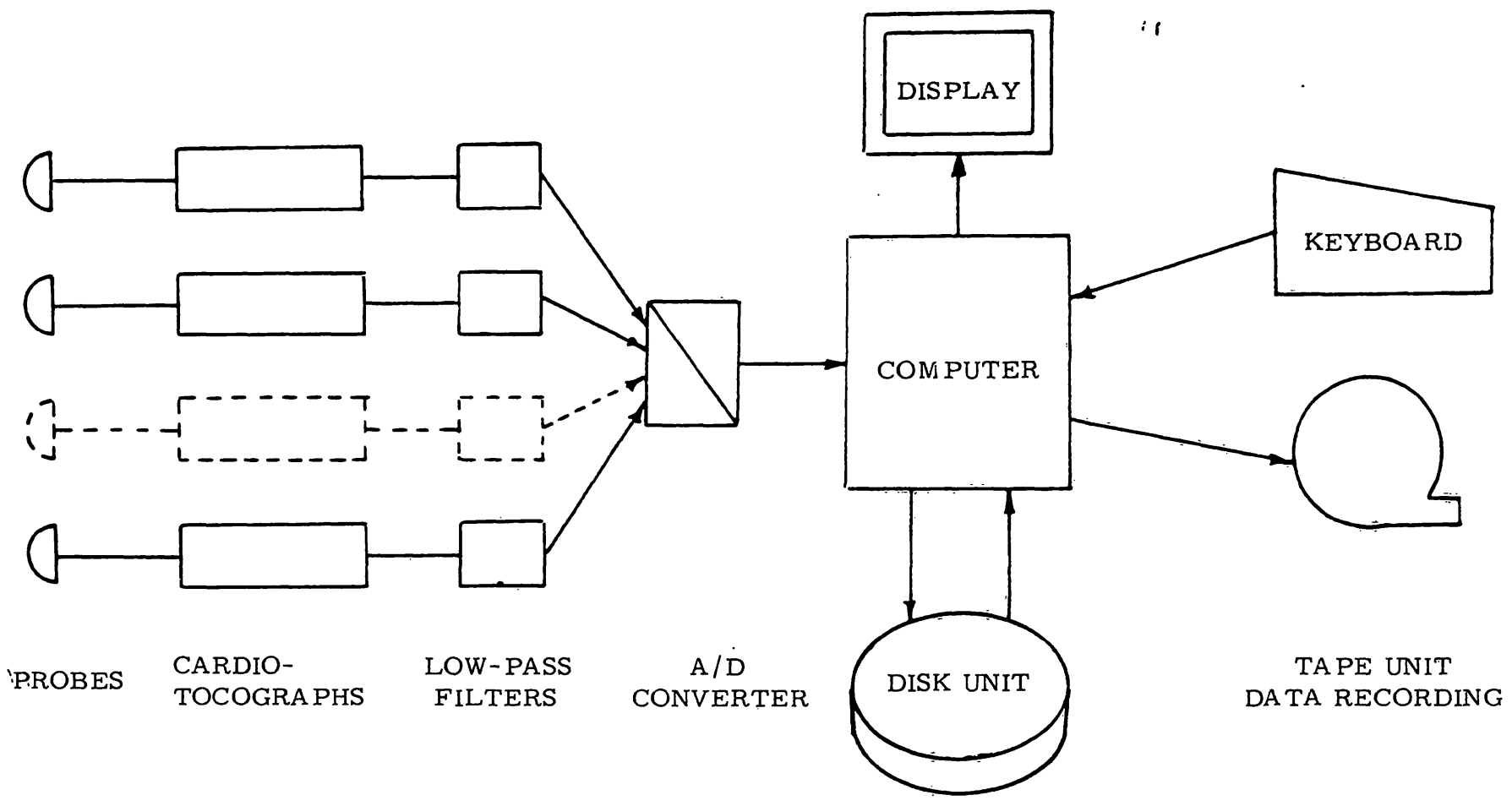

Fig. 5. Hardware configuration for monitoring.

computer. Clinical information for a correct judgement concerning each labor period will be supplied by the physician by means of the keyboard; this information will be added to parameters extracted for each labor period on the tape records.

\section{Conclusions}

Twenty-five parameters have been proposed for the description of each uterine contraction. These parameters were chosen in order to get more information on contraction behaviour. The above present the main characteristics of the intrauterine pressure waveform which are usually observed in

\section{Summary}

In recent years many authors have considered evaluation of uterine contractility by means of analysis of amniotic fluid pressure variations. The reason for this is the introduction in obstetrical management of equipment for the recording of amniotic fluid pressure variations which is a powerful facility for elinical investigation, particularly, if it is considered that previous research has been based upon clinical evaluations and measurements carried out by extra and intra-uterine manometers.

Important results of these studies are the definitions of two labor indices, the Montevideo unit (defined as the sum of the maxima of the pressure signal of all uterine contractions during a time interval of ten minutes) and a qualitative way by the physician. This procedure was tested using spontaneous labors.

The purpose of this research was not the definition of indices for clinical evaluation, but the realization of an analysis system which can be a powerful tool for clinical investigation; the use of these twentyfive parameters is meaningless in the case of continuous monitoring because too many data are presented to the physician. The future of this research will be a systematic investigation into the meaning of each parameter spread over a large number of iabor periods, in order to point out which parameters are most meaningful and suitable.

the Alexandria unit (which also takes into account the duration of the contraction: this unit corresponds to the Montevideo unit multiplied by the mean value of the duration of the considered contractions).

It is very difficult, however, in fact almost impossible, to summarize the evaluation of labor as the only index. Many parameters which characterize the shape, frequency and tone of contraction patterns, may be themselves important and could indicate the presence of pathological elements.

At present it is not well known which parameters are useful. Since many different sets öf parameters can be 
chosen to characterize the signal, the first point is to determine which is more important clinically.

The aim of this paper is to study a procedure of intrauterine pressure signal analysis, which allows the description of uterine contraction by a set of parameters that is interesting for research purposes during labor and suitable. for continuous monitoring. The set of parameters was chosen in order to repeat quantitatively the qualitative analysis which a physician can make by a simple inspection of the pressure signal oscillogram. Visual examination of the tocograph results is a clumsy means for evaluating labor performed by an experienced physician. It may appear that the pressure starts "suddenly" (or not) to increase and rises "quickly" (or "slowly"), then it maintains "high" (or "low") mean values for a "long" (or "short") time, with "smooth" (or "irregular") behaviour, then it decreases "quickly" (or "slowly"), until "suddenly" (or "smoothly") it reaches its basal level, which is "higher" (or "lower") than the previous one. The interval between the end of one and the beginning of another uterine contraction is "long" (or "short"), during this time the pressure is "almost" constant (or has a "drift" and/or presents "many irregularities"). Therefore the 25 chosen parameters replace quantitatively the above qualitative evaluations. These parameters are not put forward to indicate directly the presence of pathological factor, but summarize all the interesting clinical aspects of the contraction waveform for research and monitoring purposes. The parameters are extracted using a pattern recognition algorithm based on a structural representation of the contraction (Tables I, II, V).

This method has two main advantages:

i) The procedure is particularly suitable for process computers, operating in real time,

ii) The shape of contraction patterns is described by a set of parameters, any of which has an immediate meaning even for physicians who are not well acquainted with the signal theory.

For instance, the Montevideo and Alexandria units can be computed as a simple function of some considered parameters related to the contractions found in a ten minute period.

The analysis procedure has been designed in order to work in real-time, but the first results shown in this paper were obtained only by simulation of the real-time technique; the pressure signal was processed by a computer not directly connected to the pressure transducer placed in the delivery room.

Spontaneous labors were selected to evaluate the method. The results obtained indicate that the proposed method is suitable to give (by means of the twenty-five parameters) a complete clinical description of contraction behaviour during labor.

The proposed analysis system could be a powerful tool for the study of waveform contractions and continuous monitoring during labor. A statistical investigation will verify which of these indices is indicative for pathological conditions during labor.

Keywords: Contraction recognition, phrase, pattern recognition, pressure waveforms, surface structure, terminal vocabulary, uterine activity.

\section{Zusammenfassung}

Eine beschreibende Methodik für die automatische Analyse der Uteruskräfte während der Geburt.

In den vergangenen Jahren wurde die Beschreibung der uterinen Kontraktilität durch Analyse der intraamnialen Druckvariationen von vielen Autoren untersucht. Der Grund für dieses neue Interesse kann in der Einführung von Geräten für die Messung der intraamnialen Druckveränderungen in die tägliche geburtshilfliche Praxis gesehen werden. Die Möglichkeit, Druckveränderungen auf dem Oszillogramm abzulesen, ist in der Tat eine erhebliche Erleichterung für die klinische Forschung, insbesondere, wenn man bedenkt, daß die ältere Forschung auf der klinischen Beschreibung und auf Messungen basiert, die mit extra- und intrauterinen Tonometern durchgeführt worden sind. Wichtige Resultate dieser Studien waren die Definition von 2 Wehen-Indices, die Montevideo-Einheit (definiert als die Summe der Maximalwerte des Drucksignales aller uterinen Kontraktionen während eines Zeitraumes von 10 Minuten) und die Alexandria-Einheit (die zusätzlich die Dauer der Kontraktion berücksichtigt: Diese Einheit entspricht der Montevideo-Einheit multipliziert mit der mittleren Dauer der untersuchten Kontraktionen).

Es ist jedoch sehr schwierig und in der Tat fast unmöglich, die Beurteilung der Wehentätigkeit nur in einem Index zusammenzufassen. Viele Meßgrößen, welche die Frequenz und den Tonus von Kontraktionsmustern charakterisieren, könnten selbst wichtig sein und die Anwesenheit von
Pathologie anzeigen. Zur Zeit wissen wir nicht genau, welche Parameter beim Vorliegen von pathologischen Kontraktionselementen von Bedeutung sind, wenngleich einige qualitative Hinweise beobachtet wurden. Da viele verschiedene Kombinationen von Parametern ausgewählt werden können, um das Wehensignal zu charakterisieren, muß vorrangig festgestellt werden, welche Kombination für die klinische Forschung von größerem Interesse ist. Das Ziel dieser Arbeit besteht im Studium der intrauterinen Drucksignalanalyse, die eine Beschreibung der uterinen Kontraktion mit Hilfe einiger Parameter erlaubt, von welchen wir glauben, daß sie sowohl für Wehenforschungszwecke von Interesse, als auch für die kontinuierliche Überwachung geeignet sind. Die Kombination der Parameter wurde ausgewählt um eine qualitative Analyse, die der Arzt durch einfaches Betrachten der Drucksignaloszillogramme vornimmt, quantitativ $\mathrm{zu}$ wiederholen. Die optische Einschätzung eines Tokogramms für den Zweck einer Wehenbeurteilung kann in der Tat zu mühsam sein, selbst wenn dies von einem erfahrenen Arzt vorgenommen wird. So kann nicht mehr festgestellt werden, als der Druckanstieg begann, ,plötzlich“ (oder nicht) um „schnell" (oder ,langsam") anzusteigen; dann blieben "hohe" (oder „tiefe") mittlere Druckwerte für eine „lange" (oder kurze) Periode mit ,geglättetem“ (oder „irregulärem") Kurvenverlauf, dann sank der Druck "schnell" (oder „langsam") bis „plötzlich". (oder „zögernd") der Basaltonus wieder erreicht wurde, der 
„höher" (oder „tiefer") als der vorangehende war. Das Intervall $\mathrm{zwischen}$ dem. Ende einer Kontraktion und dem Anfang der nächsten uterinen Kontraktion ist ,lang“ (oder ,,kurz"), in diesem Zeitintervall ist der Druck nahezu „,konstant" (oder zeigt einen Trift und/oder weist viele Unregelmäßigkeiten auf). Die 27 ausgewählten Parameter beschreiben demnach auf quantitative Weise die oben erwähnten qualitativen Beurteilungen. Es sei vermerkt, daß die analysierten Parameter nicht vorgeschlagen wurden, um direkt die Anwesenheit von pathologischen Kontraktionselementen anzuzeigen, vielmehr wurden sie aus dem Grund vorgeschlagen, weil sie anscheinend alle interessanten klinischen Aspekte einer Kontraktionswelle für die Forschung und das Überwachungsvorhaben zusammenfassen. Diese Parameter wurden abgeleitet unter Verwendung eines Wehenerkennungs-Algorithmus, der auf der strukturellen Repräsentation einer Kontraktion basiert (Tabelle I, II und V). Diese Methode hat 2 Hauptvorteile:

1. Dieses Vorgehen ist besonders geeignet für die Verarbeitung durch Prozeßkomputer, die in real-time arbeiten

2. die Form eines Kontraktionsmusters wird durch ein Set von Meßgrößen beschrieben, von welchen jede Größe eine momentane Bedeutung hat, und zwar selbst für die Ärzte, die mit der Signaltheorie nicht gut vertraut sind. So können z.B. die Montevideound Alexandria-Einheiten als eine einfache Funktion von einigen Parametern, die mit den in einem 10Minuten-Intervall gefundenen Kontraktionen zusammenhängen, berechnet werden.

Das Analyse-Verfahren wurde entworfen, um in real-time zu arbeiten. Die in dieser Arbeit gezeigten ersten Resultate wurden jedoch nur durch Simulation einer real-timeTechnik erhalten. Das Drucksignal wurde von einem Komputer verarbeitet, der nicht direkt mit dem Drucktransducer im Gebärsaal verbunden war. Um die Methode zu überprüfen, wurden Spontangeburten ausgewählt. Die erhaltenen Resultate zeigen, daß die vorgeschlagene Methodik geeignet ist (aufgrund von 25 wohldefinierten Meßgrößen) eine vollständige klinische Beschreibung des Kontraktionsverhaltens während der Geburt zu liefern. Das vorgeschlagene Analysesystem könnte ein effektives Instrument für das Studium von Kontraktionsabläufen und für die kontinuierliche Überwachung während der Geburt sein. Das zukünftige Ziel dieser Forschung ist, die Definition von neuen Indices, die ihrëseits eine Funktion der vorgeschlagenen Parameter sind. Eine statistische Untersuchung wird herausfinden, welcher dieser Indices für pathologische Konditionen während der Geburt hinweisend ist.

Schlüsselwörter: Druckverläufe oder Flächenstruktur, Erkennen von Kontraktionen, Mustererkennung, Phrase, terminales Vokabular, uterine Aktivität.

Résumé:

Méthode descriptive d'analyse automatique des forces utérines en cours de travail

L'évaluation de la contractilité utérine par l'analyse des variations de la pression du liquide amniotique a fait l'objet de vices d'obstétrique ont été équipés des appareils nécessaires pour cela. $\mathrm{La}$ lecture rendue ainsi possible d'oscillogrammes de variations de pression facilite beaucoup, en effet, les examens cliniques alors qu'auparavant les mesures étaient effectuées à l'aide de manomètres extra et intra-utérins.

Ces études ont pour résultat important de définir deux indices de travail: l'unité Montevideo (somme des maxima des signes de pression de toutes les contractions utérines durant un intervalle de temps de dix minutes) et l'unité Alexandria (qui tient compte en plus de la durée de la contraction: cette unité correspond à l'unité Montevideo multipliée par la valeur moyenne de la durée des contractions considérées).

On ne saurait, toutefois, évaluer le travail selon un index unique car l'examen de divers autres paramètres sur la forme, la fréquence et le ton des contractions-types permet de détecter des anomalies.

On n'a pas encore réussi à déterminer quels paramètres sont les plus significatifs pour la détection d'éléments pathologiques et il importe à présent d'établir le système de paramètres le plus profitable à l'exămen clinique.

L'étude présente porte sur la recherche d'une méthode analytique des indices de pression intra-utérine pour circonscrire la contraction utérine à l'aide de divers paramètres permettant un enregistrement continu du déroulement du travail, et cela à titre de contrôle immédiat et de recherche générale. Notre système de paramètres a été établi en vue de répéter quantitativement l'analyse qualitative qu'un praticien peut faire par simple observation de l'oscillogramme des signes de pression; comme de fait, l'appréciation visuelle des résultats tocographiques - même par un praticien expérimenté - peut être trop imprécise pour servir à une analyse du travail. Pour autant qu'on le sache d'expérience, la pression commence «subitement» (ou non) à augmenter et monte «rapidement» (ou «lentement»), puis elle se maintient à une moyenne «élevée» (ou basse») pour un temps «long» (ou «brēf»), avec une courbe "régulière» (ou «irrégulière»), et décroîtenfin «rapidement» (ou «lentement») jusqu'à atteindre «brusquement» (ou «doucement») son ton bạsal qui est "plus élevé» ou «plus bas» que le précédent. L'intervalle entre la fin d'une contraction utérine et le début d'une autre est «long》 (ou "court») et, au cours de cet intervalle, la pression est «presque» constante (ou subit un «écart brusque» et!ou présente «de nombreuses irrégularités»). Les 25 paramètres sélectionnés illustrent donc de façon quantitative les observations qualitatives cidessus mentionnées. Notons que ces paramètres ne sont pas proposés pour indiquer directement la présence d'éléments pathologiques, mais pour totaliser les aspects cliniques intéressants des ondes de contraction à des fins de recherche et d'enregistrement. Les paramètres sont extraits selon un algorithme-type de détection basé sur un enregistrement structurel de la contraction (Tab. I, II, V). 
Cette méthode présente les deux principaux avantages suivants:

i) Elle est particulièrement appropriée à l'analyse électronique opérant en temps réel;

ii) et la forme des contractions-types est décrite par un ensemble de paramètres dont chacun a une signification immédiate même pour les praticiens qui ne sont pas très familiarisés avec les signes théoriques.

C'est ainsi, par exemple, que les unités Montevideo et Alexandria peuvent être enregistrées électroniquement comme une simple fonction de quelques paramètres relatifs aux contractions durant une période de dix minutes.

Le procédé analytique a été signalé selon un fonctionnellement en temps réel, mais les premiers résultats exposés dans cet article n'ont été obtenus que par simulation de la technique en temps réel; le signe de pression a été reproduit par un computer non directement relié au transducer de pression placé dans la salle d'accouchement.

On a choisi des accouchements spontanés pour évaluer la méthode. Les résultats obtenus indiquent que la méthode proposée convient à donner (au moyen des vingt-cinq paramètres établis) une description clinique complète du déroulement des contractions en cours de travail.

Lc système analytique proposé pourrait être très utile à l'étude des contractions ondulatoires et de l'enregistrement continu en cours de travail. Cette recherche a pour but de déterminer des nouveaux indices et des nouvelles fonctions des paramètres proposés. Une investigation statistique vérifiera lequel de ces indices témoigne de conditions pathologiques en cours de travail.

Mots-clés: Activité utérine, evaluation des contractions, évaluation-type, ondes de pression, phrase, structure de surface vocabulaire.

\section{Acknowledgement:}

This work was supported by the National Research Council of Italy.

\section{Bibliography}

[1] BUlOW DAVIDSEN, P. C.: Continuous monitoring of the foetal heart rate and uterine contraction during labour. Acta Obstet. Gynec. Scand. 60 (1971) 50

[2] CALDEYRo-BARCiA, R., H. AlVAREZ, S. R. M. REYNOLDS: A better understanding of uterine contractility through simultaneous recording with an internal and seven channel external method - Surg. Gyn. Obstet. 91 (1950) 641

[3] CAldey RO-BARCIA, R., S. V. POSE, H. AlVAREZ: Uterine contractility in Polyhydramnios and the effects of withdrawal of the excess of amniotic fluid. Amer. J. Obstet. Gynec. 77 (1957) 1208

[4] CALDEY RO-BARCIA, R., J. J. POSEIRO: Oxytocin and contractility of human uterus. Ann. N. Y. Acad. Sci. 75 (1959) 813

[5] CALDEYRO-BARCIA, R.: Regulation of myometrial activity in pregnancy by "Muscle" In: PAUL, W. M., E. E. DANIEL, G. M. KEY, Pergamon Press, New York 1964

[6] CHOMSKY, N.: Aspects of the theory of Syntax Cambridge Mass., MIT Press 1965

[7] COREN, R. L., A. J. CSAPO: The intraamniotic pressure - Amer. J. Obstet. Gynec., 85 (1963) 470

[8] CSAPO, A. J.: Uterine activity during human pregnancy. Acta Obstet. Gynec. Scand. 2 (1968) 81

[9] DAVYDOV, S. M.: Radiotelemetric investigation of intrauterine pressure in the process of normal labour - Akush. Ginek. (Mosk.) 4 (1970) 48

[10] EL-SAKWI, S., A. A. GAAFAR, H. K. TOPOZZADA: A new unit for evaluation of uterine activity - Amer. J. Obstet. Gynec., 98 (1967) 901
[11] EVANS, T. G.: Grammatical inference techniques in pattern analysis. Internat. Symp. Computers and Information Sci., 3rd, Bac Harbour, Florida, 1969 Academic Press, New York.

[12] FU, K. S., P. H. SWAIN: On syntactic pattern recognition - Software Engineering, Academic Press, 1971

[13] FRIEDMAN, E. A.: Labour: clinical evaluation and management. Butterworth \& Co. 1968

[14] HON, E. H.: An Atlas of foetal heart rate patterns Harty Press. Inc. New Haven, Connecticut 1968

[15] HON, E. H., R. H. PAUL: Quantitation of uterine activity - Obstet. and Gynec. 42 (1973) 368

[16] HUNTER, CH. A.: Uterine motility studies during labor - Amer. J. Obstet. Gynec. 85 (1963) 681

[17] KRAPHOL, A. J., J. DE VRIES, T. N. EVANS: Electronic control of induction of labour - Obstet. and Gynec., 25 (1965) 334

[18] KRAPHOL, A. J., G. J. MYERS, R. CALDEYROBARCIA: Uterine contraction in spontaneous labor. A quantitative study Amer. J. Obstet. Gynec., 106 (1970) 378

[19] LORAND, S.: Über einen neuen Wehenzeichnenden Apparat (Tokograph). Zentralbl. - Gynäk., 57 (1933) 554

[20] LORAND, S.: Experience with a modified tocograph - Orvosi Hetil. 80 (1936) 771

[21] LORAND, S.: Erfahrungen mit den modifizierten Tokograph - Mschr. f. Geburtsh. Gynäk. 130 (1936) 137

[22] LORAND, S.: Die tokographische Einteilung der Wehentypen bei normalen und pathologischen Geburten - Zbl. Gynäk. 61 (1937) 1285 
[23] MURPHY, J. B.: Uterine contractility in pregnancy - J. B. Lippincot Company, 1947

[24] MYERS, GRANT, J., A. J. KRAPHOL, J. VARNER: Fourier series analysis of Amniotic Fluid Contraction Waves - Obstet. and Gynec. 30 (1967) 164

[25] PAVLIDIS, T.: Linguistic Analysis of Waveforms International Symp. Computer and Information Sci., 3rd, Bac Harbour, Florida, Academic Press, New York 1969

[26] PERSIANINOV, L. S.: Use of radiotelemetry in studies of uterine contraction activity during labour. Int. J. Gynec. Obstet. 4 (1971) 141

[27] PERSIANINOV, L. S., S. V. DAVYDOV: A radiotelemetric study of uterine activity in labour. Acta Obstet. Gynec. Scand. 50 (1971) 269

[28] PERSIANINOV, L. S.: The possibilities and prospects of intravenous tocography and radiotelemetry in investigations of the uterine contractile capacity. Akush. Ginek (Mosk.) 47 (1971) 10

[29] REYNOLDS, S. R: H., J. S. HARRIS, I. H. KAISER - Clinical measurement of uterine forces. Springfield Press., Illinois 1964

[30] ROMANINI, C., A. BOMPIANI: L'integrazione elettronica del tracciato tocografico. Risultati preliminari - Atti del $54^{\circ}$ Congresso Naz. Soc. It. Ost. Ginec. 508 (1970)
[31] ROMANINI, C., A. BQMPIANI: Il monitoraggio elettronico della contrazione uterina: valutazione mediante integratore digitale. Acta med. rom., 10 (1972) 49

[32] Romanini, C., S. C. Oliva, M. MatteuCCI, A. BOMPIANI: Ann. di Ost. Ginec. e Med. Perin. 9 (1972) 705

[33] ROMANINI, C., S. C. OLIVA, A. BOMPIANI: La valutazione dell'attività úterina - Ann. Ost. e Ginec. e Med. Perinat. (in press)

[34] SCHATZ: Über die Formen der Werkenkurve und die Peristaltik des menschlichen Uterus. - Arch. Gynäk. (1886) 27

[35] SCHATZ: Der Geburtsmechanismus der Kopfendlagen. Leipżiğ, 1868

[36] SCHULMAN, H., S. L. ROMMEY: Variability of uterine contractions in normal human parturition. Obstet. and Gynec. 36 (1970) 215

[37] STOOKEY, R. A., R. J. SOKOL, M. G. ROSEN: Abnormal contractions patterns in patients monitored during labour Obstet. and Gynec. 42-43, (1973) 359

[38] TURnbUlL, A. C.: Physical methods of measurement - Obstetrics and Gynaecology Symposium, Dundee, 1961

Received October 23, 1975. Accepted April 30, 1976.

Prof. L. Gagliardi

Istituto di Patologia Ostetrica e Ginecologica dell'Università

Via Ventimiglia, 3

I-10126 - Torino/Italy 